Dhaka Univ. J. Biol. Sci. 31(1): 147-157, 2022 (January) DOI: https://doi.org/10.3329/dujbs.v31i1.57923

\title{
EFFECTS OF TEXTILE WASTEWATER ON GROWTH AND YIELD COMPONENTS OF RICE (ORYZA SATIVA L.)
}

\author{
Monoara Begum*, Md. Nasimul Gani ${ }^{1}$ And Md. Didar-Ul-Alam ${ }^{2}$ \\ Soil and Environmental Sciences, University of Barishal, Barishal-8254, Bangladesh
}

Key words: Textile wastewater, rice, growth and yield component.

\begin{abstract}
An experiment was conducted to study the effect of textile wastewater on growth and yield components of rice (Oryza sativa L.). The treatments were $\mathrm{T}_{1}$ : Control, T2: Sole RDF (Recommended Dose of Fertilizer) + FW (Fresh Water), T3: 50\% RDF + 25\% TWW (Textile Waste Water), T4: 50\% RDF + 50\% TWW, T5: 50\% RDF $+75 \%$ TWW, T6: 50\% RDF + 100\% TWW. The highest plant height (134.1 $\mathrm{cm})$, tiller number at maturity stage $\left(344 / \mathrm{m}^{2}\right)$, straw yield $(6.94 \mathrm{t} / \mathrm{ha})$, grain yield $(4.25 \mathrm{t} / \mathrm{ha})$, panicle number $\left(306 / \mathrm{m}^{2}\right)$, panicle length $(24.57 \mathrm{~cm})$, number of grain/ panicle (118.5), percent of filled grain/panicle $(85.07 \%)$ and 1000 -grain weight $(13.77 \mathrm{gm})$ were found in $\mathrm{T}_{2}$. And the second highest plant height $(124.2 \mathrm{~cm})$, tiller number at maturity stage $\left(342 / \mathrm{m}^{2}\right)$, grain yield $(3.97 \mathrm{t} / \mathrm{ha})$, panicle number $\left(301 / \mathrm{m}^{2}\right)$, panicle length $(24.12 \mathrm{~cm})$, number of grain per panicle $(117.2)$, percent of filled grain/panicle $(84.17 \%)$ and 1000 -grain weight $(13.37 \mathrm{gm})$ were found in $\mathrm{T}_{4}$. And $\mathrm{T}_{5}$ gave the second highest yield of straw (6.05 $\left.\mathrm{t} / \mathrm{ha}\right)$. Although highest values were found in $\mathrm{T}_{2}$, but statistically the achievements indicate that there was little difference between the $\mathrm{T}_{2}$ and $\mathrm{T}_{4}$ treatments. The overall findings of this study indicated that where fresh water is scarce application of 50\% RDF along with $50 \%$ TWW irrigation may be a good indicator to achieve better growth and yield of rice.
\end{abstract}

\section{Introduction}

Rice is the staple food crop of Bangladesh and it occupies about $80 \%$ of the country's total cropped area. It provides nearly $48 \%$ of rural employment, about two-third of total calorie supply and about one-half of the total protein intake of an average person in the country. Rice sector contributes one-half of the agricultural GDP and one-sixth of the national income in Bangladesh. The population of Bangladesh is still growing by two million every year and may increase by another 30 millions over the next 20 years. Therefore, rice yield needs to be increased ${ }^{(1)}$. Irrigation water is a critical factor for crop production in our country, which can make a crop either a success or a failure. The rainfall is not evenly distributed throughout the year. About $95 \%$ of the total rainfall

\footnotetext{
*Author for correspondence: \bmonoara@ymail.com>. 'Fiber Quality Improvement Division, Bangladesh Jute Research Institute Dhaka Bangladesh. ${ }^{2}$ Vice Chancellor, Noakhali Science and Technology University, Noakhali, Bangladesh.
} 
occurs during April to October, leaving the remaining five months of the year essentially dry ${ }^{(2)}$. Textile industry is one of the most important and rapidly developing industrial sectors in Bangladesh. This industry releases highly polluted and toxic wastewaters which are discharged into sewers and drains without any kind of treatment ${ }^{(3)}$. In areas where irrigation water is scarce, the use of industrial wastewater is an important source for supplementing water resources. Furthermore, reuse may help alleviate industrial disposal problems by reducing the volume of industrial wastewater involved(4). Wastewater containing nutrients can be used extensively for irrigation. It can be considered as both a resource and a problem ${ }^{(5)}$. Wastewater can supply a significant amount of nutrients which can improve soil fertility, plant growth and crop production, reducing the consumption of required fertilizers ${ }^{(6)}$. Although this water is considered to be a rich source of organic matter and plant nutrients, it also contains sufficient amounts of soluble salts and heavy metals such as Iron $(\mathrm{Fe})$, Copper $(\mathrm{Cu})$, Zinc $(\mathrm{Zn})$, Lead $(\mathrm{Pb})$, Nickel (Ni), Selenium (Se), Mercury (Hg), Chromium (Cr), Arsenic (As), and Aluminum $(\mathrm{Al})^{(7)}$. Some of them are toxic to plants and some others to both plants and animals. Keeping all these facts in view the study was envisaged to assess the effect of textile wastewater on the growth and yield components of rice (Oryza sativa L.).

\section{Material and Methods}

A field experiment was conducted in Bangladesh Jute Research Institute, Central Station, Dhaka to find out the effect of textile wastewater irrigation on growth and yield of rice.Treatments were T1: Control, T2: Sole RDF (Recommended Dose of Fertilizer) + FW(Fresh Water), $\mathrm{T}_{3}: 50 \%$ RDF + 25\% TWW (Textile Waste Water), $\mathrm{T}_{4}: 50 \% \mathrm{RDF}+50 \%$ TWW, T5: 50\% RDF + 75\% TWW, T6: 50\% RDF + 100\% TWW. The numbers of plots were 18 and dimension of each plot was $3 \mathrm{~m} \times 3 \mathrm{~m}$. The space between the plots, blocks and around the field was 1.0 meter.The land was ploughed thoroughly and puddle with $3 \mathrm{~cm}$ to $5 \mathrm{~cm}$ of standing water in the field. Then the land was leveled after puddling to facilitate a uniform distribution of water and fertilizers. Full dose of $\mathrm{P}$ as triple super phosphate (TSP), $\mathrm{K}$ as muriate of potash (MoP), $\mathrm{S}$ as gypsum and $\mathrm{Z}$ as zinc oxide were applied as a basal during final land preparation. Nitrogen as urea was applied in three equal splits, the first one as immediately after seedling establishment, the second one at early tillering stage and third one at 5-7 days before panicle initiation stage. Transplanted Aman rice Binashail variety was used in the experiment. Seedlings were transplanted in line at a distance of $30 \mathrm{~cm}$ interval. Rice was harvested 36 to 40 days after flowering stage. It was harvested when the moisture content of the rice grain was 20 to $25 \%$. Small bundles were beaten on bare ground. Grains were then partially cleaned and removed from the threshing floor. Before storage, the grain were dried and cleaned then stored in bags.The plant height and tiller number of rice were recorded at 20 (early tillering stage: ETS), 40 (maximum tillering stage: MTS), 60 (panicle initiation stage: PIS) and 90 
(maturity: Mat.) day after transplanting (DAT). The yield of straw and grain, yield contributing components of rice (panicle number $/ \mathrm{m}^{2}$, panicle length, number of grain/panicle, percentage of filled grain/panicle and 1000-grain weight) were recorded at the time of harvest.

For irrigation textile wastewater was collected from Gazipur districts, where most of our textile mills are situated. After land preparation soil samples were collected from 0$15 \mathrm{~cm}$ plough layer. One $\mathrm{kg}$ of each composite soil sample was taken in plastic container for chemical analysis. One litter of textile wastewater was also taken in a plastic bottle. Then physical and chemical characteristics of the soils and water were determined. Standard methods were followed for the determination of the following properties:

Table 1. Initial physical and chemical properties of the soil used.

\begin{tabular}{|c|c|}
\hline Parameters & Values \\
\hline \multicolumn{2}{|l|}{ Particle size analysis ${ }^{(8)}$} \\
\hline Sand (\%) & 42 \\
\hline Silt (\%) & 45 \\
\hline Clay (\%) & 13 \\
\hline Textural class & Loam \\
\hline $\mathrm{pH}^{(9)}$ & 6.2 \\
\hline $\mathrm{EC}\left(\mathrm{dSm} \mathrm{m}^{-1}\right)$ & 1.3 \\
\hline Organic matter $(\mathrm{OM}) \%^{(10)}$ & 2.42 \\
\hline Total Nitrogen $(\mathrm{N}) \%\left({ }^{(9)}\right.$ & 0.121 \\
\hline Potassium (K) Cmol(+) $\mathrm{K}^{-1}$ & 0.31 \\
\hline Calcium (Ca) $\mathrm{Cmol}(+) \mathrm{K}^{-1}$ & 3.27 \\
\hline Magnesium (Mg) Cmol(+) $\mathrm{K}^{-1}$ & 0.93 \\
\hline Available phosphorus (P) $\mathrm{mgkg}^{-1}$ & 26.51 \\
\hline Available Sulphur (S) $\mathrm{mgkg}^{-1}$ & 29.11 \\
\hline Available copper $(\mathrm{Cu}) \mathrm{mgkg}^{-1}$ & 0.74 \\
\hline Available iron $(\mathrm{Fe}) \mathrm{mgkg}^{-1}$ & 199.80 \\
\hline Available manganese $(\mathrm{Mg}) \mathrm{mgkg}^{-1}$ & 2.42 \\
\hline Available zinc (Zn) $\mathrm{mgkg}^{-1}$ & 20.15 \\
\hline Available lead $(\mathrm{Pb}) \mathrm{mgkg}^{-1}$ & 29.78 \\
\hline Available cadmium (Cd) $\mathrm{mgkg}^{-1}$ & 0.238 \\
\hline Available nickel (Ni) mgkg-1 & 23.48 \\
\hline Available chromium $(\mathrm{Cr}) \mathrm{mgkg}^{-1}$ & 31.12 \\
\hline
\end{tabular}


Table 2. Chemical properties of textile wastewater.

\begin{tabular}{lc}
\hline Parameters & Values \\
\hline $\mathrm{pH}$ & 7.2 \\
$\mathrm{EC}\left(\mathrm{dSm}^{-1}\right)$ & 2.43 \\
$\mathrm{TDS}\left(\mathrm{mgkg}^{-1}\right)$ & 805 \\
$\mathrm{DO}\left(\mathrm{mgkg}^{-1}\right)$ & 4.2 \\
$\mathrm{BOD}\left(\mathrm{mgkg}^{-1}\right)$ & 13.4 \\
Total Nitrogen $(\%)$ & 0.6 \\
Potassium $\left(\mathrm{mgkg}^{-1}\right)$ & 0.61 \\
Calcium $\left(\mathrm{mgkg}^{-1}\right)$ & 0.73 \\
Magnesium $\left(\mathrm{mgkg}^{-1}\right)$ & 0.25 \\
Phosphorus $\left(\mathrm{mgkg}^{-1}\right)$ & 40.27 \\
Sulphur $\left(\mathrm{mgkg}^{-1}\right)$ & 70.48 \\
Copper $\left(\mathrm{mgkg}^{-1}\right)$ & 1.73 \\
Iron $\left(\mathrm{mgkg}^{-1}\right)$ & 1.11 \\
Manganese $\left(\mathrm{mgkg}^{-1}\right)$ & 0.069 \\
Zinc $\left(\mathrm{mgkg}^{-1}\right)$ & 0.10 \\
Lead $\left(\mathrm{mgkg}^{-1}\right)$ & 0.0001 \\
Cadmium $\left(\mathrm{mgkg}^{-1}\right)$ & 0.0032 \\
Nickel $\left(\mathrm{mgkg}^{-1}\right)$ & 0.351 \\
Chromium (mgkg-1) & 0.152 \\
\hline
\end{tabular}

\section{Results and Discussion}

Plant height: At all growth stages plant height of rice significantly $(P \leq 0.05)$ increased with textile wastewater irrigation as compared with control (Fig. 1). At ETS the highest plant height $45.9 \mathrm{~cm}$. was recorded at $\mathrm{T}_{2}$ (sole RDF) and among the treatments of TWW the highest plant height $43.7 \mathrm{~cm}$. was found with $\mathrm{T}_{4}$. The lowest plant height at this stage $35.2 \mathrm{~cm}$. was recorded with $\mathrm{T}_{1}$ (control). Similarly, at MTS and PIS the highest plant height 90.10 and $130.30 \mathrm{~cm}$, respectively were recorded in $\mathrm{T}_{2}$. And among the treatments of effluent the highest plant height 88.9 and $122.8 \mathrm{~cm}$. were recorded, respectively at MTS and PIS with $\mathrm{T}_{4}$. The lowest plant height at MTS and PIS 75.3 and $100 \mathrm{~cm}$., respectively were found with $\mathrm{T}_{1}$ (control). Consequently, at Mat. stage highest plant height $134.1 \mathrm{~cm}$.was measured at the treatment of sole inorganic fertilizer plot in $\mathrm{T}_{2}$ and among the effluent treated plots the highest plant height $124.2 \mathrm{~cm}$.was found at $\mathrm{T}_{4}$. At this stage plant height of $T_{4}$ and $T_{5}$ were found statistically similar. The lowest plant height at this stage $112.2 \mathrm{~cm}$. was found with $\mathrm{T}_{1}$ (control). Considering the plant height at maturity stage the treatments may be arranged in order of $\mathrm{T}_{2}>\mathrm{T}_{4}>\mathrm{T}_{5}>\mathrm{T}_{6}>\mathrm{T}_{3}>\mathrm{T}_{1}$. 
Tiller number: Study revealed that tiller number of rice increased with irrigation of TWW up to $50 \%$ concentration and over this rate there was decreasing trend in all the stages (Fig. 2). At ETS tiller number of rice increased in all the treatments significantly $(\mathrm{P} \leq 0.05)$ as compared with control but irrigation of different concentration of textile wastewater had no significant difference between each other for the production of tiller number of rice at this stage. At ETS the highest tiller number $234 / \mathrm{m}^{2}$ was observed in $\mathrm{T}_{2}$ and the lowest tiller number $217 / \mathrm{m}^{2}$ was observed with $\mathrm{T}_{1}$ (control). At MTS the highest tiller number $612 / \mathrm{m}^{2}$ was observed in $\mathrm{T}_{2}$ and among the treatments of effluent the highest tiller number at this stage $585 / \mathrm{m}^{2}$ was observed in $T_{4}$. The lowest tiller number

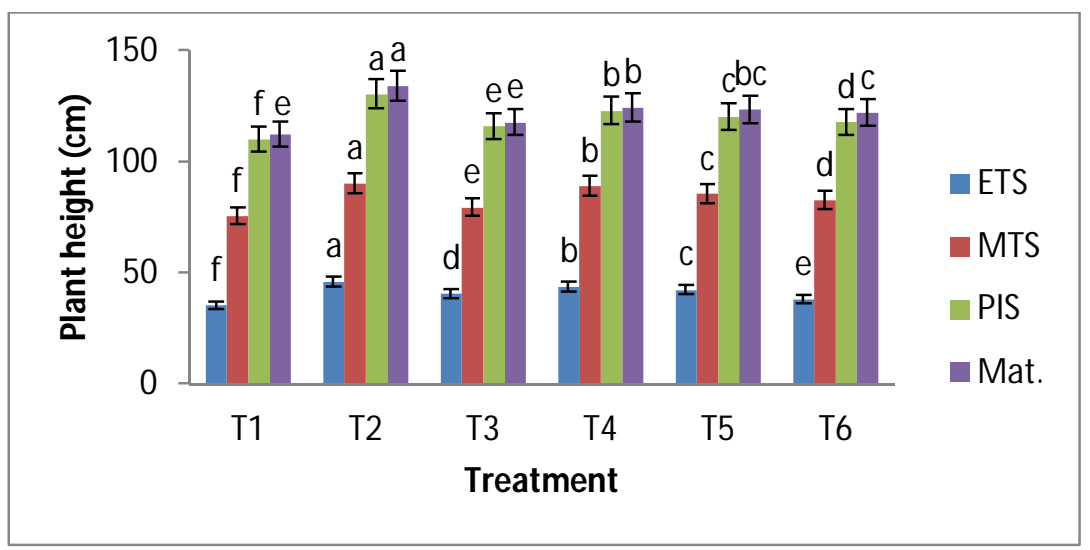

Fig. 1. Effects of textile wastewater on plant height at different growth stages of rice.

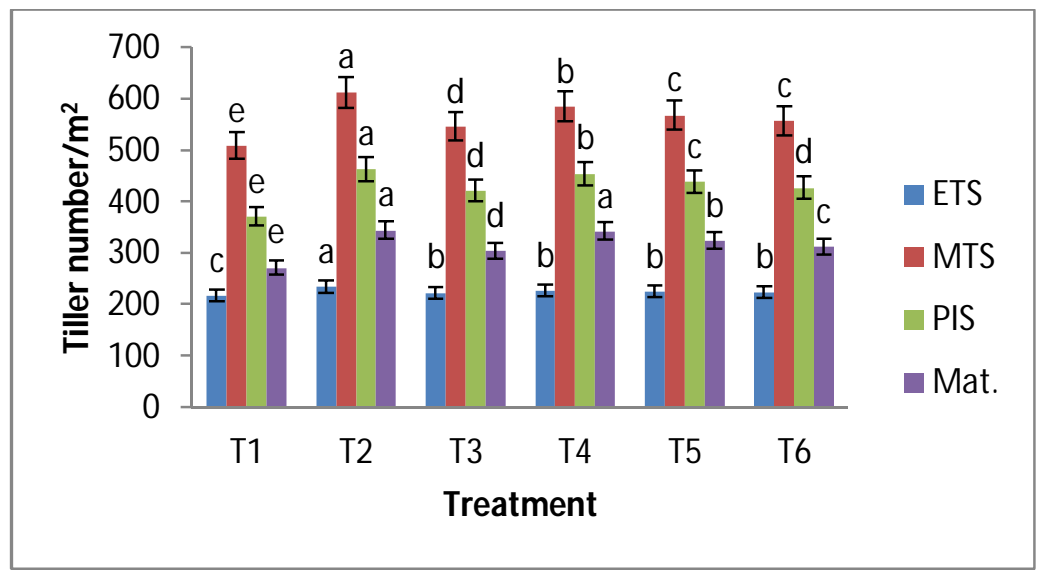

Fig. 2. Effects of textile wastewater on tiller number of rice plant at different growth stage.

$509 / \mathrm{m}^{2}$ was observed with $\mathrm{T}_{1}$ (control). The results revealed that at MTS stage irrigation of textile wastewater up to $50 \%$ concentration increased significantly $(P \leq 0.05)$ but the incremental rate over $50 \%$ TWW causes decreased significantly $(P \leq 0.05)$ the tiller number 
of rice. Similarly, at PIS the highest tiller number $463 / \mathrm{m}^{2}$ was observed in $T_{2}$ and among the treatments of wastewater the highest tiller number $454 / \mathrm{m}^{2}$ was observed in $\mathrm{T}_{4}$. The lowest tiller number $371 / \mathrm{m}^{2}$ was observed with $\mathrm{T}_{1}$ (control). The results showed that irrigation of textile waste water up to $50 \%$ concentration also increased the tiller number of rice significantly $(P \leq 0.05)$ at this stage after that further higher rate it decreased. At Mat. stage the highest tiller number $344 / \mathrm{m}^{2}$ was found in $\mathrm{T}_{2}$ and among the treatments of wastewater the highest tiller number at this stage $\left(342 / \mathrm{m}^{2}\right)$ was found in $\mathrm{T}_{4}$. And the lowest tiller number $271 / \mathrm{m}^{2}$ was recorded with $\mathrm{T}_{1}$ (control). The results indicated that at Mat. stage $\mathrm{T}_{4}$ had no significant difference with $\mathrm{T}_{2}$ for the production of tiller.

Straw and grain yield: The straw and grain yield significantly $(P \leq 0.05)$ increased with textile wastewater irrigation as compared with control (Fig. 3 and 4). The yield of straw ranged between 3.47 and $6.94 \mathrm{t} / \mathrm{ha}$. Highest straw yield $6.94 \mathrm{t} /$ ha was found with $\mathrm{T}_{2}$ and among the treatments of TWW the highest straw yield $6.05 \mathrm{t}$ /ha was observed with $\mathrm{T}_{5}$. Straw yield increased up to irrigation of $75 \%$ TWW, and then gradually decreased. Straw yield in $\mathrm{T}_{4}$ and $\mathrm{T}_{5}$ did not significantly vary with each other. The lowest straw yield was found with $\mathrm{T}_{1}$ (control).

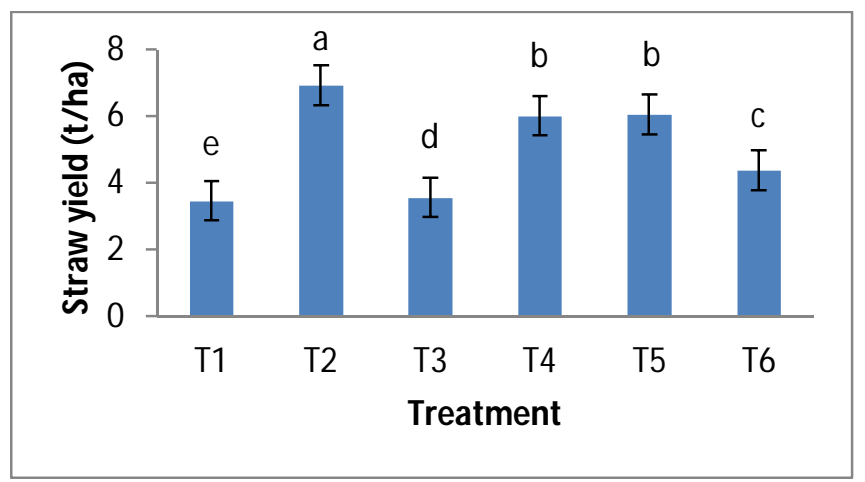

Fig. 3. Effects of textile wastewater on straw yield of rice.

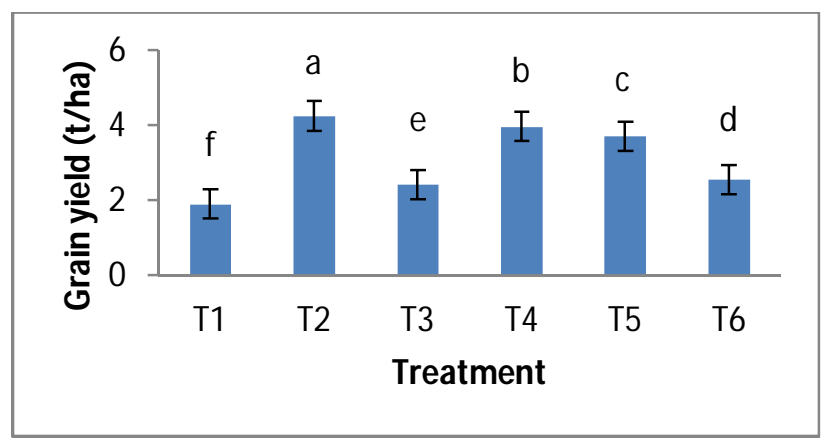

Fig. 4. Effects of textile wastewater on grain yield of rice. 
The range of grain yield was found between 1.9 and $4.25 \mathrm{t} / \mathrm{ha}$. The highest grain yield $4.25 \mathrm{t}$ /ha was found with $\mathrm{T}_{2}$ and among the treatments of TWW the highest grain yield $3.97 \mathrm{t}$ /ha was observed with $\mathrm{T}_{4}$. Grain yield increased up to irrigation of $50 \% \mathrm{TWW}$, then gradually decreased. Minimum grain yield was found with $\mathrm{T}_{1}$ (control). Grain yield in all the treatments significantly varied with each other treatments. It may therefore be suggested that textile wastewater acts as a supplement to mobile compounds of nutrients which increased the growth rate of rice plant. Textile wastewater application increased germination, growth parameters, yield and yield contributing characters ${ }^{(11)}$. Irrigation of wastewater for rice cultivation must bring benefits for farmers mainly by increased yield with less amount of fertilizers, it also has potential to cause drawbacks to human health and the environment ${ }^{(12)}$. Root and shoot length of rice plants decreased with an increase in heavy metals present effluents level in the soil(13). Begum et al.(4) found that fresh water irrigation gave the tallest plants because it contained considerable amount of macro and micro-nutrients and contained heavy metals within permissible limit. Adequate nutrients supply and presence of heavy metals within permissible limit in irrigation water enhanced root and shoot growth and thereby resulted the highest plant height, and tillers per hill. Yoon et al.(14) found that the irrigation did not adversely affect the growth and yield of rice, resulting in up to $50 \%$ greater yield than rice without wastewater irrigation. Wastewater irrigation brought $10-15 \%$ higher yield of rice crops ${ }^{(15)}$. Yasmin et al.(16) found that wastewater showed increasing inhibitory effects with increasing concentrations while concentrations below $50 \%$ showed positive effects on germination and growth of lentil seedlings. Nagajyothi et al.(17) and Nath et al. ${ }^{(18)}$ also reported that textile wastewater irrigation improve crop growth and yield.

Panicle number: The panicle number per meter square increased significantly $(P \leq 0.05)$ in all treatments over the control (Fig. 5). The ranges of panicle number of rice were from 173 to $306 / \mathrm{m}^{2}$. Application of $100 \% \mathrm{RDF}$, with fresh water contributed 306 panicle numbers per meter square, which was the highest number of panicle. Among the treatments of TWW the highest panicle number per meter square 301 was found with $T_{4}$, where 50\% RDF along with 50\% TWW was applied. The lowest panicle number $/ \mathrm{m}^{2} 173$ was found with $\mathrm{T}_{1}$ (control).

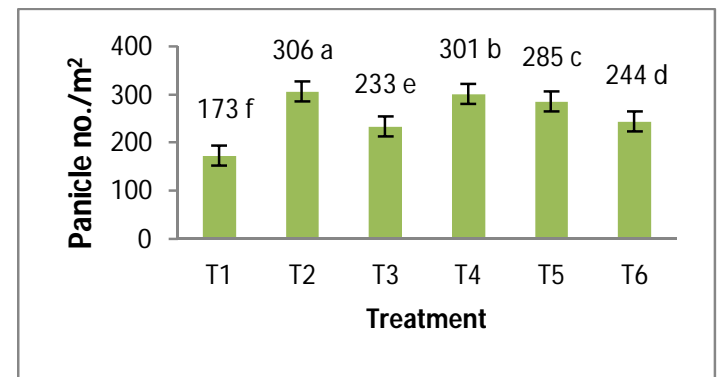

Fig. 5. Effects of textile wastewater on panicle number of rice. 
Panicle length: As highest panicle length of rice $24.57 \mathrm{~cm}$. was found with $\mathrm{T}_{2}$ (sole RDF).The treatments with TWW also increased the panicle length and showed great variation compared to control $\left(\mathrm{T}_{1}\right)$. The result revealed that the increased of concentration of textile wastewater irrigation up to $50 \%$ the panicle length of rice was increased, after that decreased. Among the treatments of TWW the highest panicle length $24.12 \mathrm{~cm}$. was observed with $\mathrm{T}_{4}$, where $50 \%$ RDF along with 50\% TWW was applied. Control $\left(\mathrm{T}_{1}\right)$ showed the lowest panicle length, which was $12.67 \mathrm{~cm}$ (Fig. 6).

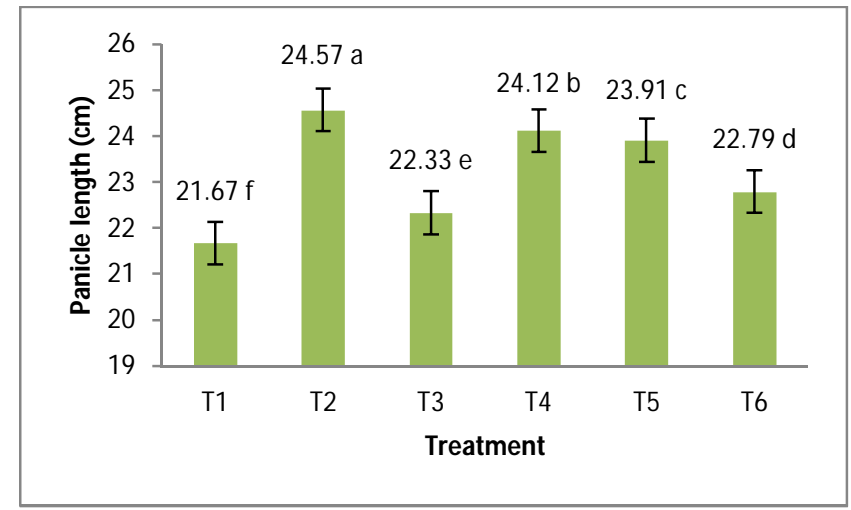

Fig. 6. Effects of textile wastewater on panicle length of rice.

Number of grain per panicle: The number of grain per panicle of rice increased significantly $(P \leq 0.05)$ in all treatments as compared with control, except $\mathrm{T}_{3}$, where $50 \%$ RDF along with $25 \%$ TWW was applied (Fig. 7). Number of grain per panicle ranged between 113.75 and 118.5. Sole RDF with fresh water showed 118.5 grain per panicle, which was the highest. Among the treatments of TWW the highest number of grain per panicle 117.2 was found with $\mathrm{T}_{4}$, where $50 \%$ RDF along with $50 \%$ TWW was applied. The lowest number of grain per panicle 113.75 was found with $\mathrm{T}_{3}$, where $50 \%$ RDF along with $25 \%$ TWW was applied.

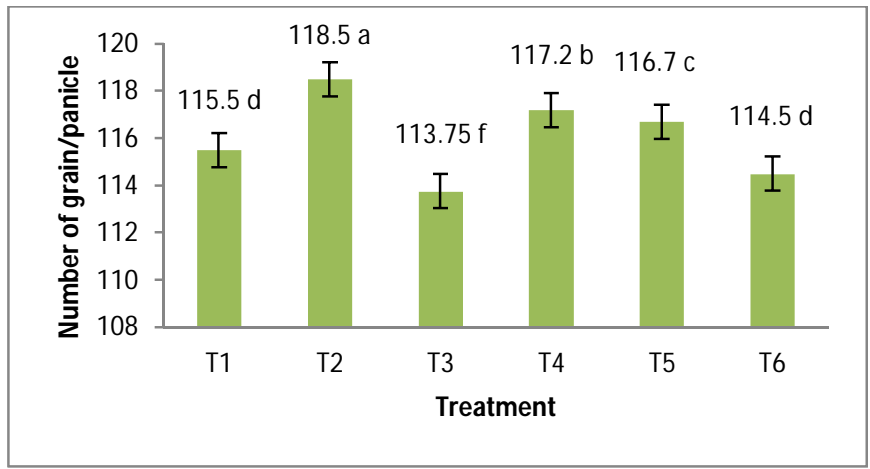

Fig. 7. Effects of textile wastewater on number of grain per panicle. 
Per cent of filled grain per panicle: Irrigation of textile wastewater enhanced the percentage of filled grain per panicle of rice significantly $(\mathrm{P} \leq 0.05)$ as compared with control (Fig. 8). Highest percentage of filled grain per panicle (85.07) was found with $\mathrm{T}_{2}$. The result revealed that with the increased of concentration of textile wastewater irrigation up to $50 \%$, the percentage of filled grain per panicle were increased, after then decreased. Among the treatments of TWW the highest percentage of filled grain per panicle 84.17 was observed with $\mathrm{T}_{4}$, where $50 \%$ RDF along with 50\% TWW was applied. Control $\left(\mathrm{T}_{1}\right)$ showed the lowest percentage of filled grain.

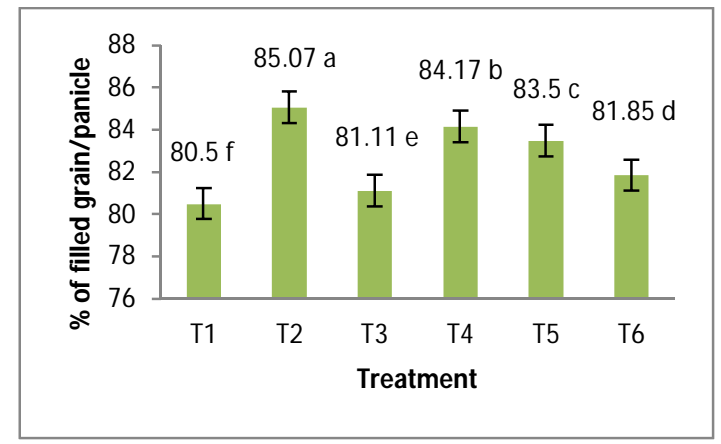

Fig. 8. Effects of textile wastewater on percent of filled grain per panicle.

1000-grain weight: The weight of 1000-grain of rice increased significantly ( $\mathrm{P} \leq 0.05)$ in all treatments as compared with control, except $\mathrm{T}_{6}$ where 50\% RDF along with 100\% TWW was applied (Fig. 9). 1000-grain weight ranged between 11.15 and 13.77 gm. Sole RDF treatment $\left(T_{2}\right)$ showed the highest 1000-grain weight, which was 13.77 gm. Among the treatments of TWW the highest 1000-grain weight $13.37 \mathrm{~g}$ was found with $\mathrm{T}_{4}$, where $50 \%$ RDF along with 50\% TWW was applied. The result revealed that 1000- grain weight with $\mathrm{T}_{4}$ did not significantly vary with $\mathrm{T}_{5}$. The lowest 1000 -grain weight 11.15 was found with $\mathrm{T}_{6}(50 \% \mathrm{RDF}+100 \% \mathrm{TWW})$.

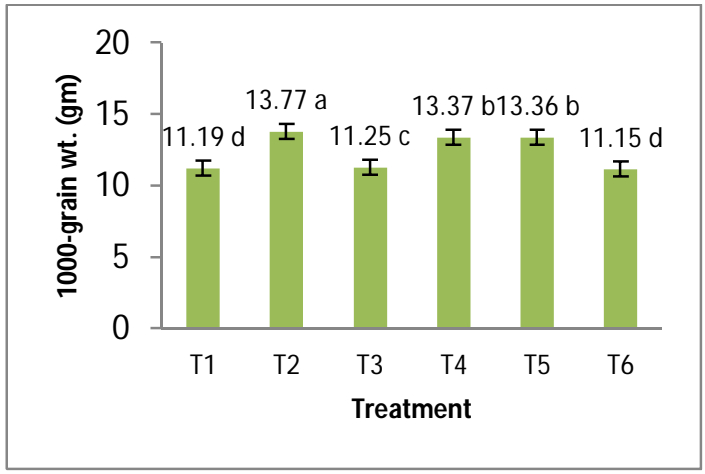

Fig. 9. Effects of textile wastewater on 1000-grain weight of rice. 
Length of ear $/ \mathrm{m}^{-2}$, No. of grain ear $/ \mathrm{m}^{-2}$ and yield $(\mathrm{Q} / \mathrm{ha})$ were found higher in textile effluent irrigated crop in comparison to control ${ }^{(19)}$. The reason for positive impact of wastewater irrigation on crop was due to presence of nutrients i.e. $\mathrm{P}, \mathrm{K}$ and $\mathrm{S}$ which nourish the experimental crop better than control crop.Yaseen et al.(20) observed that application $50: 50 \%$ of waste and canal water improved plant height, number of pod plant(-1), pod length of field mustard .The scientists suggest that wastewater utilization along with canal water mixing might be an effective approach for enhancing growth and yield of field mustard. Yaseen et al.(21) found that the application of liquid NPK fertilizer with end drain textile wastewater increased plant height, spike length, flag leaf length, root length, number of tillers $\left(\mathrm{m}^{-2}\right)$, number of fertile tillers $\left(\mathrm{m}^{-2}\right), 1000$-grain weight, grain yield and straw yield of wheat.The textile mill effluent is toxic to crop and it can be used for irrigation purpose after a proper treatment with appropriate dilution ${ }^{(22)}$.

From the above findings, it could be concluded thatboth $\mathrm{T}_{2}$ and $\mathrm{T}_{4}$ improves growth and yield component of rice. So, it could be suggested that where fresh water irrigation is scarce, $50 \%$ RDF along with $50 \%$ diluted textile wastewater might be applied to achieve better growth and yield components of riceand monitoring of heavy metals should be conducted regularly for minimize the human health risks.

\section{Acknowledgement}

I am extremely grateful to honorable prime minister for awarding me the scholarship to carry out such valuable research work. I am also grateful to the BJRI authority for giving me the opportunity for the experiments and using the laboratory.

\section{References}

1. Website 1: http://www.knowledgebank-brri.org/riceinban.php

2. Rashid MA, AFM Saleh and LR Khan 2005. Water saving and economics of alternate wetting and drying irrigation for rice. Bang. J. Wat. Res. Res. 20: 81-93.

3. Islam MM, K Mahmud, O Faruk and MS Billah 2011. Textile Dyeing Industries in Bangladesh for Sustainable Development. Int. J. Env. Sci. Dev. 2: 6-16.

4. Begum RA, MW Zaman, ATMAI Mondol, MS Islam and KMF Hossain 2011. Effects of textile industrial waste water and uptake of nutrients on the yield of rice. Ban.J. Agric. Res. 36: 319-331.

5. Begum M, MN Gani and MD Alam 2018. Effect of textile effluent on yield of jute leaves (Corchorus capsularis) in winter season. J. Biod. Conserv. Biores. Manage. 4: 53-59.

6. Hanjra MA, J Blackwell, G Carr, F Zhang and TM Jackson 2012. Wastewater irrigation and environmental health: implications for water governance and public policy. Int. J. Hyg. Env. Health. 215(3): 255-269.

7. Mohammed SA and JO Folorunsho 2015. Heavy metals concentration in soil and Amaranthus retroflexus grown on irrigated farmlands in the Makera area, Kaduna, Nigeria. J. Geogra. Reg. Plan. 8(8): 210-217. 
8. Bouyoucos GJ 1962. Hydrometer method improved for making particle size analysis of soils. Agron. J. 54: 464-465.

9. Jackson ML 1973. Soil Chemical Analysis, Prentice Hall, Inc. Engle wood cliffs, N. J., USA.

10. Walkley A and IA Black 1934. An examination of Degtsareff method for determining soil organic matter and proposed modification for the chromic acid titration method. Soil Sci. 37: 29-38.

11. Saravanamoorthy MD and KBD Ranjitha 2007. Effect of textile waste water on morphophysiology and yield on two varieties of peanut (Arachis hypogaea L.). J. Agric. Tech. 3(2): 335-343.

12. Pham DD and T Watanabe 2017. Current Perspective on Irrigation and Drainage. (Published by INTECH), pp. 37.

13. Raju K, V Vishnuvardhan and T Damodharamet 2015. Industrial Effluents Effect on Seedling Growth of Rice and Wheat (Oryza Sativa L. and Triticum Vulgare L.). Int. J. Rec. Sci. Res. 6(7): 4935-4939.

14. Yoon CG, SK Kwun and JH Ham 2001. Effects of treated sewage irrigation on paddy rice culture and its soil. Irrig. Drain. 50(3): 227-236.

15. Thu NN 2001. Urbanization and wastewater reuse in peri-urban areas: a case study in Thanh Tri District, Hanoi City. IWMI Work. 30: 16-17.

16. Yasmin A, S Nawaz and SM Ali 2011. Impact of industrial effluents on germination and seedling growth of Lens esculenttum varieties. Pak. J. Bot. 43: 2759-2763.

17. Nagajyothi PC, N Dinakr, S Suresh, YU daykiran, C Suresh and T Damodharam 2009. Effect of industrial effluent on the morphological parameters and chlorophyll content of green gram (Phaseolus aureusRoxb). J. Env. Bio. 30: 385-388.

18. Nath K, D Singh, S Shyam and YK Sharma 2009. Phytotoxic effects of chromium and tannery effluent on growth and metabolism of Phaseolus mungo Roxb. J. Env. Bio. 30: 227-234.

19. Pandey R and J Singh 2015. Effect of textile factory effluent irrigation on productivity of wheat crop. Int. J. Sci. Env. Tech. 4(3): 727-736.

20. YaseenM, MZ Aziz, A Komal and M Naveed 2017. Management of textile wastewater for improving growth and yield of field mustard (Brassica campestris L.). Int. J. Phyto. 19(9): 798-804.

21. Yaseen M, MZ Aziz, AA Jafar, M Naveed and M Saleem 2016. Use of textile waste water along with liquid NPK fertilizer for production of wheat on saline sodic soils. Int. J. Phyto. 18(5): 502-8.

22. Mycin TR 2016. Toxic Effect of Textile Mill Effluent on Cow Pea (Vigna unguiculata L.) Walp. Int. J. Env. Agric. Res. 2(5): 51-56. 